\title{
THE IMPACT FACTORS OF CORPORATE SOCIAL RESPONSIBILITY DISCLOSURE
}

\author{
Maidani \\ maidani@dsn.ubharajaya.ac.id \\ Murti Wijayanti \\ Rakhmat Purnomo \\ Universitas Bhayangkara Jakarta raya \\ Jl. Harsono Rm Dalam No.46, Ragunan, Jakarta Selatan, DKI Jakarta 12550
}

received: 19/6/19; revised: 24/9/20; approved: 14/12/20

\begin{abstract}
This research study purpose is to analyze the impact of profitability, independent members of commissioner board, leverage and public shareholders on Corporate Social Responsibility (CSR) Disclosure by using 27 companies listed on Indonesia stock exchange and publishing Sustainability Report for the year during 2015 - 2017 as a sample. Using multiple linear regression as data analysis method, the results show that the proportion of independent board of commissioner of their existence can be a counterweight to various parties so as to encourage companies to disclose CSR, while the higher leverage level, the more likely the company will violate the credit agreement so that the company will seek to report higher earnings now. Therefore, in order for reported earnings to be high, the manager reduces costs, including the costs of disclosure of social responsibility. While profitability, and public share ownership have no effect on CSR Disclosure.
\end{abstract}

\section{Keywords: CSR disclosure; sustainabilityreport; profitability; independentmembers of commissioner board; leverage; public shareholders}

\section{INTRODUCTION}

The development of corporate social responsibility (CSR) in Indonesia is actually inseparable from the society community around the company environment. This situation is in accordance with company goals that cannot be separated between economic and social goals. Therefore, CSR is a necessity for companies. The existence of CSR in Indonesia is legally strengthened by Constitution of 2007 Number 40 on Limited Company, particularly in Article 74 paragraph (1) stated every company running a business is obliged to carry out social and environmental responsibility. In practice, this social and environmental responsibility reporting is especially applied to companies that listed on Indonesia's Stock Exchange and disclosed in the Sustainability Report, which explains the company's performance report in terms of implementing social and environmental responsibility for 1 (one) year.

In signal theory, company expected to provide good and relevant information to stakeholders, including creditors, investors, government, consumers, suppliers and the public. The information conveyed not only contain financial performance, but also company activities in the form of concern and awareness of social and environmental aspects.
According to legitimacy theory, the company tries to ensure activities and performance are acceptable to the community. By using the sustainability report, it gives the impression that company has carried out social and environmental responsibility activities, thereby gaining legitimacy from the community. However, the legitimacy theory stated by Donovan and Gibson (2000) related inversely between profitability and social responsibility disclosure. When the company earns high profits, it does not need to report other detailed information rather than the successful company's financial performance. On the other hand, if the company at low level of profitability, it needs to provide more detail related information other than financial performance, with the hope stakeholders can receive good information about the company's performance apart from financial performance. such as social and environmental performance. Thus, stakeholders can get good news as a whole about the company's performance.

According to stakeholder theory, each corporation must consider the existence of surrounding environment, both internal and external. Corporation need to implement a framework and decision-making policy that supports goal achievements, such as economic measurement which tends to be shareholder oriented as well as business stability and sustainable guarantee as 
a considering environmental factors. The information about corporation concern on environment can be seen at disclosure of CSR which is part of the Sustainability Report as the essence of corporation performance in environmental, economic, social, labor, human rights and the natural environment. The environmental reporting can be defined as an "umbrella" that describes various way about disclosure information of corporation environmental activities (Sen, et al., 2011). CSR is a concept that is becoming more and more important for the private sector to integrate the economic, social, and environmental imperatives of their activities (Woodhouse, 2018). It is becoming increasingly aware that CSR affects firm outcomes, from stock performance and valuation to corporate policies (Dunbar, et. al., 2020).

(Agudelo, et. al., 2019) classify the periodization history of CSR in the world. Began in 1950 as the initial period of CSR, 1970's CSR and management began synergized, 1980's the operationalization of CSR, 1990's globalization and CSR, in 2000's recognition and implementation of CSR and in 2010's CSR and the creation of shared value. According to (Tamvada, 2020), CSR literature has widely acknowledged that corporates and society are interlinked, and that corporates must act for the benefit of society. In the competitive world, stakeholders always respond positively to CSR initiatives. This positive response leads to good consumer response which turns into customer loyalty (Islam, et. al., 2012). Therefore, the company existence depends on how to carry out its social responsibility to the community, which is disclosed in detailed in the company's sustainability report.

Literature reviews the determinants of CSR disclosure both in developed and developing countries (Ali, et. al., 2017), analysed companies behaviour types based on their CSR disclosure practices (FernandezFeijoo, et. al., 2014), and many factors influences the implementation of CSR disclosures. External factors are mainly related to organization perceptions or surrounding communities towards social and environmental corporate performance while internal factors are top management corporate leadership that sees CSR a source of opportunities to gain competitive advantage (responsibility is opportunity). According to (Kolk, 2016) studies on international business and CSR have developed over the last 50 years with sub-themes: environment; ethics, rights and responsibilities; poverty and (sustainable) development. Therefore, quite number of researchers have revealed that internal factors such company's performance and increasingly company's characteristics play a role as a driver CSR in the future. several CSR practices in developing countries as stated by (Frederiksen, 2019) that in many cases, aimed at maintaining the status quo. Seeking to reduce risk to investments and produce operational stability in a context of considerable economic and environmental upheaval. In practice varies from country to country. Given that it is strictly situation based, the content of the concept of CSR in one country may have marginal or no significance in another country (Lindman et al., 2020). (Fordham \& Robinson, 2018) was found that engaging a diverse array of company employees and stakeholders into CSR in varied institutional settings drove plurality in CSR practice, which extended the outcomes and linkage to societal benefit.

Profitability is the company's ability to gain profits at the certain level of sales, assets, and share capital. Return On Asset (ROA) shows corporate assets used to generate profits of each dollar (Suroso et al., 2017). This research using ROA as a variable, because it can directly asses the level company's profitability obtained from managed assets, so that the company's efficiency in managing its assets can be known.

Customer satisfaction for the product of the company will generate high profit and the ability company to generate profit will certainly attract investors to invest in company (Evandini \& Darsono, 2014). The higher level of profitability achieved, then the greater level of CSR will disclose by the company. There are various results of research to examine the relationship between profitability and CSR. Appropriately the independent board of commissioners has no direct and indirect relation to stakeholder or shareholder of the company, therefore their existence is expected to encourage CSR disclosure. In several studies, the relationship between independent commissioners and CSR disclosure also shows different result in each study, such as independent commissioners does not impact on CSR disclosure (Nugroho \& Yulianto, 2015), and (Muslim, 2019) different from research taken by (Nurkhin, 2010), (Santioso \& Chandra, 2012), (Hermawan \& Gunardi, 2019), and (Hapsoro \& Fadhilla, 2017) stated independent commissioners have a positive and significant impact on CSR disclosure.

According to agency theory, leverage has negative effect in disclosure of social responsibility. Corporate with high level of leverage tend to reduce CSR disclosure in avoiding bad image of the debtors. Several study research that have been conducted the influence leverage on CSR disclosure have produced many different results. The leverage size carried out by the corporate management does not have an influence in disclosure of CSR (Situmorang, 2017), (Deitiana, 2015) and (Wagiu \& Mekel, 2014). Besides, other factor like public ownership also show different study results. Adnantara (2008) study stated public share ownership has an effect on CSR disclosure, while (Nur \& Priantinah, 2012), (Evandini \& Darsono, 2014) stated, public share ownership has no effect on CSR disclosure, (Indraswari \& Astika, 2014) stated, public share ownership has negative effect on CSR disclosure.

Based on previously descriptions, this research study is going to determine the impact variables of 
profitability, independent board of commissioners, leverage, and public shares ownership to CSR disclosure. Result of this study are expected not only to strengthen the existing theories but also to add information for corporate decision makers in conveying CSR.

\section{METHODS}

This study analyse empirically the factors influenced the level of CSR disclosure in the Company's Sustainability Report. The hypothesis that has been formulated will be tested, with several research methods that have been designed according to the variables that have been studied. Thus, this research is expected to produce accurate data. This study uses a population of publicly traded companies listed on the Indonesia stock exchange. the sample in this study using purposive sampling. The sample selection criteria in this study are as follows: (1) Companies listed on the Indonesian stock exchange for the period 2015, 2016 and 2017; (2) Companies that publish complete financial and annual reports as well as sustainability reports. use of go public companies that publish sustainability reports, because these companies tend to have visibility from stakeholders, high political risk, and face high competition. Companies that are included in the high profile category are generally companies that get the spotlight from the public because their operational activities have the potential to intersect with broad interests (stakeholders).

The previously formulated hypothesis research are: (1) Profitability has positive effect on CSR Disclosure; (2) The Independent Board of Commissioners proportion has positive effect on CSR Disclosure; (3) Leverage has negative effect on CSR Disclosure; (4) The public share ownership has positive effect on CSR Disclosure. The framework research study depicts in Figure 1.

CSR Disclosure as an independent variable is measured using indicators from the Global Reporting Initiative (GRI) or G4 with the 91 disclosures consists of : economic (EC), environment (EN), labour (LA), human rights (HR), society (SO) and product responsibility (PR).

While profitability is measured using ROA(return on Asset) ratio by comparing net profit with company total asset, the independent board commissioner variables measured by comparing the independent board commissioner to total board of commissioners, leverage using debt equity ratio by comparing total debt with total asset, and public shares ownership is measured proportionally as a percentage by comparing the shares held publicly at the end year. This study research using 27 data companies which consists of companies engaged in the automotive, financial, mining, cement manufacturing, agribusiness and property industries that issues sustainability report and have been listed on Indonesia Stock Exchange Market during 2015, 2016 and 2017. Data analysis method by multiple regression analysis model, by previously testing and processing the data before analyzed. This method is used by researchers because the study does not want an analysis of the entities (individuals) and the effect of changes in the data period.

It can be seen that the CSR variable has the lowest value of 0.14 , a maximum of 0.60 , a mean of 0.3302 and a standard deviation of 0.12597 . This shows that the average company from the 81 samples of this study, only $33.02 \%$ level of CSR disclosure, even though the company is classified as a large company and publishes a sustainability report. The standard deviation is less than 3 , meaning that the data variance is not too spread out and the data is further processed by regression.

Based on normality statistic test using Kolmogorof Smirnof (K-S) method, the Asymp. Sig value is 0,062 greater than 0,05 . It can be concluded the residual values in this study are normally distributed (Table 1).

The multicollinearity test proves there were no independent variables had a tolerance value $>0.10$ while the calculation VIF value is $<10$. This concluded the variable data in this study does not occur multicollinearity between independent variables in the regression model.

This test uses the Glejser method. The results for each independent variable has a sig value $>0.05$. Therefore, all independent variables in this study are free from heteroscedasticity.

\section{RESULTS}

F statistical test shows the $F$ value is 3.221 with probability of 0.017 (Table 2). The probability value has a smaller level of significance determined by the researcher, which is equal to 5 percent. It means the regression model can be used to predict CSR, which profitability, independent commissioners proportion, leverage, and public share ownership simultaneously affect to CSR disclosure.

Profitability variable is measured by ratio Return On Asset (ROA) has a coefficient - 0,449 and significant value 0,031 (Table 3 ). It means, the significant value 0,031 is greater than 0,05 indicating the level of probability has a significant influence on CSR disclosure.

Independent board of commissioner proportion variable has a coefficient 0,133 and significant value 0,191 . It means, the significant value 0,191 is greater than 0,05 indicating the independent board of commissioner proportion variable has no significant influence on CSR disclosure.

Leverage (LEV) variable has a coefficient $-0,123$ and significant value 0,062 . It means, the significant value is greater than 0,05 indicating leverage variable has not influenced on CSR disclosure.

Public share ownership variable has a coefficient 0,269 and significant value 0,025 . It means, this significant value is lower than 0,05 indicating the variable has influenced on CSR disclosure. 
Table 4 explains the adjusted R Square $\left(\mathrm{R}^{2}\right)$ is $10 \%$, it means the low adjusted R Square in this study shows there are other variables have a greater influence on CSR disclosure.

\section{DISCUSSIONS}

The first hypothesis which states profitability has influenced on disclosure CSR is accepted. That is, the profit size affects corporation to disclose CSR. This study result is inline with agency theory which states the higher profit will support corporation to disclose social information wider, and that will be a concern for the community if the high profit corporation not involved in social activity, they will get a worse image. Therefore corporation must prepare funds for expenses regarding to social responsibility. High profit margins will encourage managers to provide more detailed information about the company, because they also want to convince investors about the company's profitability which later will support the provision of compensation for them as well. In addition, wider disclosure is intended to reduce agency conflicts. Thus, management shows that the earnings are not only used for their own interests, but also for the benefit of investors through social disclosures carried out. This study research is in accordance with (Hapsoro \& Sulistyarini, 2019) and (Indraswari \& Astika, 2014) who found the profitability variable has impact on CSR disclosure.

This study research is failed to support legitimize theory stated profitability has a negative impact to disclose CSR according to (Donovan \& Gibson, 2000). Other than that, this study research is contrary to (Moratis \& van Egmond, 2018), (Hermawan \& Mulyawan, 2014), (Gemitasari \& Nursiam, 2011), (Evandini \& Darsono, 2014) and (Permatasari, 2013) who found the profitability level not affected to CSR disclosure.

The second hypothesis which states independent board of commissioner proportion variable has positive influenced on disclosure CSR is not accepted. This is because the lower proportion of independent board of commissioner which is averagely equal to $47,70 \%$ means supervision within the company has not been maximized. Unproportional number of independent commissioner board with total commissioner board affected to decision making process which not encourage the dislosure of CSR. Otherwise, independent board of commissioner who does not have any direct activity nor operational relation will not affected the decision making process as study research by (Majidah $\&$ Sihite, 2014) and so (Nugroho \& Yulianto, 2015). They research concluded the independent board of commissioner proportion variable not affected to CSR Disclosure. This study research is contrary to (Nurkhin, 2010), and (Santioso \& Chandra, 2012).
The third hypothesis which states leverage has an impact on CSR Disclosure is not accepted. This study result is not inline with agency theory which explain the level of leverage has negative influence on CSR disclosure, even though most of corporation sample have a high level of leverage about $60 \%$ and it can not encourage them to disclose their social information. In this case, the disclosure of social information does not need to be done by a corporation to attract both investor and creditor because it already has a number source of internal capital.

The study result with leverage factor is not inline with research by (Zanirah, 2015) who found leverage has negative impact on CSR Disclosure. Those contrary with study research by (Evandini \& Darsono, 2014) who found leverage has positive impact on CSR Disclosure. However, the study result is in accordance with by (Reni \& Anggraini, 2006), (Utami \& Prastiti, 2011), and (Hidayat, 2017) who did not find the leverage impact on CSR Disclosure.

The fourth hypothesis which state public share ownership has an impact on CSR Disclosure is accepted. The average value of public share ownership is $22 \%$ and can encourage CSR disclosure. This research supports the argument : good quality corporation will intentionally provide good signals, which is social responsibility, so public can distinguish it from others and hopefully increasing the value of the corporation itself.

The study result with public shares ownership factor is inline with research conducted Adnantara (2008) who found the impact of public share ownership on CSR disclosure, but contrary inline with research by (Nur \& Priantinah, 2012), (Indraswari \& Astika, 2014) which show public shares ownership has no impact on CSR disclosure.

\section{CONCLUSIONS}

Based on data analyzed, it concludes that profitability in partial has an impact to CSR disclosure which means the profit size obtained by the company affected to the extent of CSR disclosure. The independent board of commissioners proportion partially does not significantly influenced CSR disclosure due to the uncomparable number of independent commissioners to board commissioners in making decision to encourage CSR disclosure. Leverage partially has no impact on CSR disclosure because the company does not need to disclose social information to attract investors or creditors, it has a strong source internal capital itself. Public share ownership has a significant positive impact on CSR disclosure, while simultaneously profitability, board independent commissioner proportions, leverage and public share ownership factors are significantly affected to CSR disclosure. 


\section{REFERENCES}

Adnantara, K. F. 2008. Pengaruh Struktur Kepemilikan Saham dan Corporate Social Responsibility pada Nilai Perusahaan. 1990, 107-113.

Agudelo, M.A.L., Jóhannsdóttir, L. and Davídsdóttir, B., 2019. A literature review of the history and evolution of corporate social responsibility. International Journal of Corporate Social Responsibility, 4(1), pp.1-23.

Ali, W., Frynas, J.G. and Mahmood, Z., 2017. Determinants of corporate social responsibility (CSR) disclosure in developed and developing countries: A literature review. Corporate Social Responsibility and Environmental Management, 24(4), pp.273-294.

Deitiana, T., 2015. The Determinant of CSR Disclosure of Mining Industry Listed in Indonesia Stock Exchange. Asian Business Review, 5(3), pp.141-148.

Donovan, G., \& Gibson, K. 2000. Environmental Disclosure in the Corporate Annual Report: A Logitudinal Australian Studi. Paper for Presentation in the 6th Interdisciplinary Environmental Association Conferene.

Dunbar, C., Li, Z.F. and Shi, Y., 2020. CEO risk-taking incentives and corporate social responsibility. Journal of Corporate Finance, 64, p.101714.

Evandini, C., \& Darsono. 2014. Faktor - Faktor yang Berpengaruh Terhadap Pengungkapan Tanggung Jawab Sosial Perusahaan pada Perusahaan Manufaktur yang Terdaftar di BEI. Diponegoro Journal Of Accounting, 3(3), 1-11.

Fernandez-Feijoo, B., Romero, S. and Ruiz-Blanco, S., 2014. Women on boards: Do they affect sustainability reporting?. Corporate Social Responsibility and Environmental Management, 21(6), pp.351-364.

Fordham, A.E. and Robinson, G.M., 2018. Mapping meanings of corporate social responsibility-an Australian case study. International Journal of Corporate Social Responsibility, 3(1), pp.1-20.

Frederiksen, T., 2019. Political settlements, the mining industry and corporate social responsibility in developing countries. The Extractive Industries and Society, 6(1), pp.162-170.

Gemitasari, R., \& Nursiam. 2011. Analisis FaktorFaktor yang Mempengaruhi (Studi Empiris pada Perusahaan Manufaktur yang Terdaftar di Bursa Efek Indonesia Tahun 2009-2011). Peran Perbankan Syariah Dalam Penguatan Kapasitas UMKM Menuju Kemandirian Ekonomi Nasional, 978-979.

Hapsoro, D. and Fadhilla, A.F., 2017. Relationship analysis of corporate governance, corporate social responsibility disclosure and economic consequences: Empirical study of indonesia capital market. The South East Asian Journal of Management.
Hapsoro, D. and Sulistyarini, R.D., 2019. The effect of profitability and liquidity on CSR disclosure and its implication to economic consequences. The Indonesian Accounting Review, 9(2), pp.143-154.

Hermawan, A. and Gunardi, A., 2019. Motivation for disclosure of corporate social responsibility: evidence from banking industry in Indonesia. Entrepreneurship and Sustainability Issues, 6(3), p.1297.

Hermawan, M. and Mulyawan, S., 2014. Profitability and corporate social responsibility: An analysis of Indonesia's listed company. Asia Pacific Journal of Accounting and Finance, 3(1).

Hidayat, D.W.W., 2017. The Influence of Size, Return on Equity, and Leverage on the disclosure of the Corporate Social Responsibility (CSR) in Manufacturing Companies.

Indraswari, G. A. D., \& Astika, I. B. P. 2014. Pengaruh Profit Abilitas, Ukuran Perusahaan, dan Kepemilikan Saham Publik pada Pengungkapan CSR. E-Jurnal Akuntansi Universitas Udayana, 3, 816-828.

Islam, Z.M., Ahmed, S.U. and Hasan, I., 2012. Corporate social responsibility and financial performance linkage: Evidence from the banking sector of Bangladesh. Journal of Organizational Management, 1(1), pp.14-21.

Kolk, A. 2016. The social responsibility of international business: From ethics and the environment to CSR and sustainable development, Journal of World Business, 51(1);23-34.

Lindman, Å., Ranängen, H. and Kauppila, O., 2020. Guiding corporate social responsibility practice for social license to operate: A Nordic mining perspective. The Extractive Industries and Society, 7(3), pp.892-907.

Majidah dan Sihite, S. A. 2014. Faktor-faktor yang mempengaruhi Pengungkapan Tanggung Jawab Sosial pada Perusahaan. Jurnal Universitas Telkom, pp:1- 19.

Moratis, L. and van Egmond, M., 2018. Concealing social responsibility? Investigating the relationship between CSR, earnings management and the effect of industry through quantitative analysis. International Journal of Corporate Social Responsibility, 3(1), pp.1-13.

Muslim, L.A.S., 2019. The Effect of Company Size (SIZE), Leverage, Independent Board of Commissioners, and Profitability on Corporate Social Responsibility Disclosure (Empirical Study on Mining Companies Listed on the Indonesia Stock Exchange (IDX) for the 2012-2016 Period). Nugroho, M. N., \& Yulianto, A. 2015. Pengaruh Profitabilitas dan Mekanisme Corporate Governance Terhadap Penggunaan CSR Perusahaan Terdaftar JII 2011-2013. Accounting Analysis Journal, 4(1), $1-12$. 
Nur, M., \& Priantinah, D. 2012. Analisa Faktor-faktor yang Mempengaruhi Pengungkapan Corporate Social Responsibility di Indonesia (Studi Empiris pada Perusahaan Berkategori High Profile yang Listing di Bursa Efek Indonesia). Jurnal Nominal, I(1), 22-34.

Nurkhin, A. 2010. Corporate Governance dan Profitabilitas, Pengaruhnya Terhadap Pengungkapan CSR Sosial Perusahaan. Dinamika Akuntansi, 2(1), 46-55.

Permatasari, P. 2013. Hubungan Kausalitas antara Kinerja Sosial dan Ekonomi Perusahaan. Trikonomika, 12(1), 93. https://doi.org/10.23969/ trikonomika.v12i1.465

Reni, F., \& Anggraini, R. 2006. Pengungkapan Informasi Sosial dan Faktor-Faktor yang Mempengaruhi Pengungkapan Informasi Sosial dalam Laporan Keuangan Tahunan (Studi Empiris pada Perusahaan-Perusahaan yang terdaftar Bursa Efek Jakarta ). Simposium Nasional Akuntansi, $1-21$.

Santioso, L., \& Chandra, E. 2012. Pengaruh Profitabilitas, Ukuran Perusahaan, Leverage, Umur Perusahaan, dan Dewan Komisaris Independen dalam Pengungkapan Corporate Social Responsibility. Bisnis Dan Akuntansi, 14(1), 17-30.

Sen, M., Mukherjee, K., \& Pattanayak, J. K. 2011. Corporate environmental disclosure practices in India. 12(2), 139-156.

Situmorang, E., 2017. Pengaruh Pengungkapan Corporate Social Responsibility terhadap Return

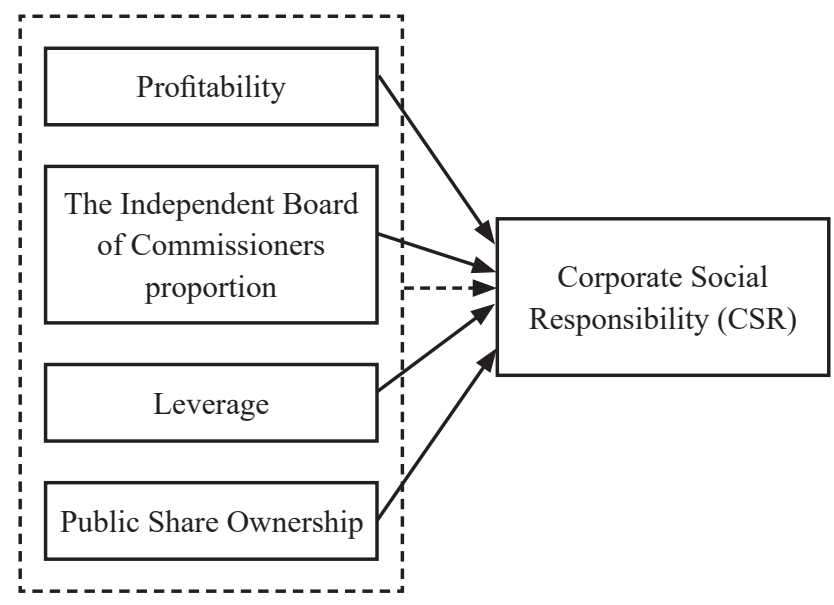

Figure 1. Research framework
On Equity (Studi Empiris pada Perusahaan BUMN yang Terdaftar di Bursa Efek Indonesia Periode 2013-2015) (Doctoral dissertation, Universitas Kristen Maranatha).

Suroso, S., Widyastuti, T., Salim, M. N., \& Setyawati, I. 2017. Intellectual Capital and Corporate Governance in Financial Performance Indonesia Islamic Banking. 7(11), 96-103.

Tamvada, M. 2020. Corporate social responsibility and accountability: a new theoretical foundation for regulating CSR. International Journal of Corporate Social Responsibility, 5(1). https://doi.org/10.1186/ s40991-019-0045-8

Utami, S., \& Prastiti, S. D. 2011. Pengaruh Karakteristik Perusahaan Terhadap Social Disclosure. Jurnal Ekonomi Bisnis, 16(1), 63-70.

Wagiu, F.A. and Mekel, P.A., 2014. The Effect Of Firm Size, Profitability, Leverage And Board Size on Disclosure of Corporate Social Responsibility in Company's Annual Reports. Jurnal EMBA: Jurnal Riset Ekonomi, Manajemen, Bisnis dan Akuntansi, 2(3).

Woodhouse, T., 2018. A Community Unlike Any Other: Incorporating Fansubbers into Corporate Capitalism on Viki.com (Doctoral dissertation).

Zanirah, D., 2015. Faktor-Faktor Yang Mempengaruhi Luas Pengungkapan Corporate Social Responsibility (Csr) Dalam Laporan Tahunan Perusahaan (Studi Empiris Pada Perusahaan Manufaktur Yang Terdaftar Dalam Bursa Efek Indo (Doctoral dissertation, Universitas Brawijaya).

Table 1. Normality Test

One-Sample Kolmogorov-Smirnov Test

\begin{tabular}{|c|c|c|}
\hline & & $\begin{array}{l}\text { Unstandardized } \\
\text { Residual }\end{array}$ \\
\hline $\mathrm{N}$ & & 81 \\
\hline \multirow[t]{2}{*}{ Normal Parameters ${ }^{\mathrm{a}, \mathrm{b}}$} & Mean & .0000000 \\
\hline & Std. Deviation & .11647888 \\
\hline \multirow[t]{3}{*}{ Most Extreme Differences } & Absolute & .096 \\
\hline & Positive & .096 \\
\hline & Negative & -.069 \\
\hline Test Statistic & & .096 \\
\hline Asymp. Sig. (2-tailed) & & $.062^{\mathrm{c}}$ \\
\hline
\end{tabular}

a. Test distribution is Normal.

b. Calculated from data. 
Table 2. Simultaneous Significance Test (F Test Statistic) ANOVA $^{\mathrm{a}}$

\begin{tabular}{rlrrrrr}
\hline Model & & $\begin{array}{c}\text { Sum of } \\
\text { Squares }\end{array}$ & df & $\begin{array}{c}\text { Mean } \\
\text { Square }\end{array}$ & F & Sig. \\
\hline 1 & Regression & .184 & 4 & .046 & 3.221 & $.017^{\mathrm{b}}$ \\
& Residual & 1.085 & 76 & .014 & & \\
& Total & 1.269 & 80 & & & \\
\hline
\end{tabular}

a. Dependent Variable: CSR

b. Predictors: (Constant), Saham Publik, DK Independent, Leverage, Profitability

Table 3. Significant Individual Parameter Test ( $\mathrm{t}$ test statistic) Coefficients $^{\mathrm{a}}$

\begin{tabular}{|c|c|c|c|c|c|c|c|c|}
\hline \multirow[b]{2}{*}{ Model } & & \multicolumn{2}{|c|}{$\begin{array}{c}\text { Unstandardized } \\
\text { Coefficients }\end{array}$} & \multirow{2}{*}{$\begin{array}{c}\text { Standardized } \\
\text { Coefficients }\end{array}$} & \multirow[b]{2}{*}{$\mathrm{T}$} & \multirow[b]{2}{*}{ Sig. } & \multicolumn{2}{|c|}{$\begin{array}{l}\text { Collinearity } \\
\text { Statistics }\end{array}$} \\
\hline & & $\mathrm{B}$ & Std. Error & & & & Tolerance & VIF \\
\hline \multirow[t]{5}{*}{1} & (Constant) & .314 & .072 & & 4.343 & .000 & & \\
\hline & Profitability & -.449 & .204 & -.258 & -2.202 & .031 & .820 & 1.220 \\
\hline & DK Independent & .133 & .101 & .148 & 1.320 & .191 & .899 & 1.113 \\
\hline & Leverage & -.123 & .065 & -.217 & -1.893 & .062 & .853 & 1.172 \\
\hline & Public Share & .269 & .117 & .258 & 2.292 & .025 & .889 & 1.125 \\
\hline
\end{tabular}

a. Dependent Variable: CSR

Table 4. Model Summary

\begin{tabular}{lcccc}
\hline Model & $\mathrm{R}$ & R Square & $\begin{array}{c}\text { Adjusted R } \\
\text { Square }\end{array}$ & $\begin{array}{c}\text { Std. Error of } \\
\text { the Estimate }\end{array}$ \\
\hline 1 & $.381^{\mathrm{a}}$ & .145 & .100 & .11950 \\
\hline $\begin{array}{l}\text { a. Predictors: (Constant), Public Share, DK Independent, Leverage, } \\
\text { Profitability }\end{array}$
\end{tabular}

